\title{
Alterations in lung gene expression in streptozotocin-induced diabetic rats
}

\author{
Erik van Lunteren*, Michelle Moyer and Sarah Spiegler
}

\begin{abstract}
Background: Diabetes profoundly affects gene expression in organs such as heart, skeletal muscle, kidney and liver, with areas of perturbation including carbohydrate and lipid metabolism, oxidative stress, and protein ubiquitination. Type 1 diabetes impairs lung function, but whether gene expression alterations in the lung parallel those of other tissue types is largely unexplored.

Methods: Lung from a rat model of diabetes mellitus induced by streptozotocin was subjected to gene expression microarray analysis.

Results: Glucose levels were 67 and $260 \mathrm{mg} / \mathrm{dl}(\mathrm{p}<0.001)$ in control and diabetic rats, respectively. There were 46 genes with at least \pm 1.5 -fold significantly altered expression (19 increases, 27 decreases). Gene ontology groups with significant over-representation among genes with altered expression included apoptosis, response to stress $(p=0.03)$, regulation of protein kinase activity $(p=0.04)$, ion transporter activity $(p=0.01)$ and collagen $(p=0.01)$. All genes assigned to the apoptosis and response to stress groups had increased expression whereas all genes assigned to the collagen group had decreased expression. In contrast, the protein kinase activity and ion transporter activity groups had genes with both increased and decreased expression.
\end{abstract}

Conclusions: Gene expression in the lung is affected by type 1 diabetes in several specific areas, including apoptosis. However, the lung is resistant to changes in gene expression related to lipid and carbohydrate metabolism and oxidative stress that occur in other tissue types such as heart, skeletal muscle and kidney.

Keywords: Type 1 diabetes, Lung, Gene expression

\section{Background}

Type 1 diabetes mellitus has widespread adverse effects on many tissues, including heart, kidney, retina, liver, vasculature, peripheral nerve and skeletal muscle. These perturbations contribute importantly to the heightened morbidity and mortality of subjects with diabetes. The lung is also affected by type 1 diabetes, manifested by declines in diffusion capacity, total lung capacity and forced vital capacity [1-5]. This may contribute to the reduced exercise capacity of humans with type 1 diabetes [6] and account for a portion of the increased sensation of dyspnea in diabetics when ventilation or respiratory efforts are increased $[7,8]$. Nonetheless, severe lung disease is rarely produced by diabetes, suggesting that the lung is more resistant than other organs to this disorder.

\footnotetext{
* Correspondence: exv4@cwru.edu

Pulmonary, Critical Care and Sleep Division, Department of Medicine, Louis Stokes Cleveland Department of Veterans Affairs Medical Center, Case Western Reserve University, 10701 East Boulevard, Cleveland, OH 44106, USA
}

Alveolar microangiopathy is postulated to play a prominent role in the genesis of diabetes-induced lung impairment [9]. However, the cellular events leading to lung impairment, and the reasons for the relative sparing of the lung compared with other organs such as the kidney and the eye, are not fully understood. One area with a particular paucity of information is the manner in which diabetes affects expression of genes in the lung. This contrasts with the extensive information gleaned from gene expression array studies of other tissue types, including pancreas [10], kidney [11-13], liver [14], spleen [15], adipose tissue [14], eye [16], corpus cavernosum [17], heart [18-20] and skeletal muscle [14,21-23]. Perturbations of gene expression by diabetes in these organs are large in number and magnitude, and cover many cellular processes such as carbohydrate and lipid metabolism, oxidative stress, and protein ubiquitination. The purposes of the present study were to a) determine the changes in gene expression 
in the lung due to streptozotocin-induced diabetes, including alterations in expression of genes in common gene ontology groups and b) examine the extent to which affected processes are similar to those reported for other tissue types or are unique to the lung.

\section{Methods}

Studies were performed on twelve male Wistar rats obtained from Charles River Laboratories (Wilmington, MA). All studies were approved by the institutional animal care and use committee of the Department of Veterans Affairs (Veterans Health Administration) and conformed with NIH guidelines for animal care. The streptozotocin-induced model was similar to that of Hida et al. [24]. At an age of eight weeks, seven animals were injected intraperitoneally with streptozotocin $60 \mathrm{mg} / \mathrm{kg}$ dissolved in sodium citrate buffer, and five with buffer alone. Four weeks later they were well-anesthetized with a mixture of intraperitoneal ketamine, xylazine and acepromazine following an all-night fast. Blood obtained from the tail was analyzed for glucose using a glucometer (Lifescan, Milpitas, CA). Fasting blood glucose values were $67 \pm 4 \mathrm{mg} / \mathrm{dl}$ (range 59 to 76 ) for the normal animals, and $260 \pm 13 \mathrm{mg} / \mathrm{dl}$ (range 222 to 313) for the diabetic animals $(\mathrm{P}<0.001$ by unpaired $t$ test). Both lungs from each animal were removed surgically, placed in RNAlater, and stored at $-80^{\circ} \mathrm{C}$.

Gene expression array studies were performed similar to previous investigations from our laboratory [20,25,26]. Total RNA was extracted using Trizol (GibcoBRL, Rockville, MD), and the RNA pellets were resuspended at 1 $\mu \mathrm{g}$ RNA/ $\mu \mathrm{l}$ DEPC-treated water. This was followed by a cleanup protocol with a Qiagen (Valencia, CA) RNeasy Total RNA mini kit. Total RNA was prepared for use on Affymetrix (Santa Clara, CA) microarrays, according to the directions from the manufacturer. Briefly, $8 \mu \mathrm{g}$ of RNA was used in a reverse transcription reaction (SuperScript II; Life Technologies, Rockville, MD) to generate first strand cDNA. After second strand synthesis, double strand cDNA was used in an in vitro transcription reaction to generate biotinylated cRNA. This was purified and fragmented, following which $15 \mu \mathrm{g}$ of biotin-labeled cRNA was used in a $300 \mu$ hybridization cocktail which included spiked transcript controls. $200 \mu \mathrm{l}$ of cocktail was loaded onto Affymetrix RAE 230A microarrays (Santa Clara, CA) and hybridized for $16 \mathrm{hr}$ at $45^{\circ} \mathrm{C}$ with agitation. Standard posthybridization washes and double-stain protocols used an Affymetrix GeneChip Fluidics Station 400. Arrays were scanned using a Hewlett Packard Gene Array scanner, and analyzed with Affymetrix MAS 5.0 software. The data have been deposited in the NCBI Gene Expression Omnibus (GEO, http://www.ncbi.nlm.nih.gov/geo/) and are accessible through GEO Series accession number GSE15900.
Statistical analysis of the microarray data utilized Bayesian analysis of variance for microarrays (BAM), using BAMarray software (http://www.bamarray.com) [27]. Genes identified by BAM as having significantly changed expression were then further selected based on consistent and appropriate present and absent calls per Affymetrix software. Subsequently signals were averaged for tissue from the non-diabetic and from diabetic animals, and fold changes were calculated based on average values from each group. Analysis focused on genes whose expression changed at least \pm 1.5 fold in diabetic compared with control lung tissue, unless indicated otherwise. To assign biological meaning to the group of genes with changed expression, the subset of genes which met the above criteria was analyzed with the Gene Ontology (GO) classification system, using DAVID 2.1 software (http://david.abcc. ncifcrf.gov/) [28,29]. Over-representation of genes with altered expression within specific GO categories was determined using the one-tailed Fisher exact probability modified by the addition of a jackknifing procedure, which penalizes the significance of categories with very few genes and favors more robust categories with larger numbers of genes.

Real-time PCR (RT-PCR) was used to confirm changes in gene expression as described previously [20,25,26]. Testing was done using the same lung tissue that had been used for gene expression arrays. An Applied Biosystems ABI 7900HT unit with automation attachment (Foster City, CA) was used for RT-PCR. This unit is capable of collecting spectral data at multiple points during a PCR run. To execute the first step and make archive cDNA, $3 \mu \mathrm{g}$ of total RNA was reverse transcribed in a $100 \mu \mathrm{l}$ reaction using Applied Biosystems enzymes and reagents in accordance with the manufacturer's protocols. RNA samples were accurately quantitated using a Nanodrop Technologies ND-1000 spectrophotometer (Wilmington, DE). Equal amounts of total RNA were reverse transcribed and then used in PCR amplifications. $\beta$-Actin had very little variation in expression across the sample set and therefore was chosen as the endogenous control. Since many of the target genes of interest were signaling molecules and likely to be expressed at low levels, we opted for a low dilution factor so as to create an environment more conducive to obtaining reliable results. The cDNA reaction from above was diluted by a factor of 10 . For the PCR step, $9 \mu \mathrm{l}$ of this diluted cDNA was used for each of three replicate $15 \mu \mathrm{l}$-reactions carried out in a 384 well plate. Standard PCR conditions were used for the Applied Biosystems assays: $50^{\circ} \mathrm{C}$ for $2 \mathrm{~min}$, followed by $95^{\circ} \mathrm{C}$ for $10 \mathrm{~min}$, followed by 40 cycles of $95^{\circ} \mathrm{C}$ for $15 \mathrm{sec}$ alternating with $60^{\circ} \mathrm{C}$ for 1 min each. Values for RNA abundance were normalized for each gene with respect to the endogenous control in that sample, mean values for fold changes were 
calculated for each gene, and statistical testing was performed with the unpaired t-test.

\section{Results}

There were 46 genes in the lung with diabetes-induced alterations in gene expression levels of at least \pm 1.5 -fold (Table 1). For the vast majority of the genes the magnitude of the changed expression was in the range of \pm 1.5 to \pm 2 -fold, with only 5 genes that had changed expression exceeding \pm 2 -fold and only 1 gene that had changed expression exceeding \pm 3 -fold. For the group as a whole, the number of genes with decreased expression exceeded the number with increased expression, although the only gene with a change exceeding \pm 3 -fold was one with increased expression. A complete list of these 46 genes is provided in Additional file 1: Table S1 [intended for online publication only]. Further analysis was performed using the group of all genes with at least \pm 1 . 5 -fold changed expression.

The 46 genes with altered expression were assigned to gene ontology (GO) terms using over-representation analysis. There were five specific GO terms or groups of closely related GO terms, which ranged in size from three to eight genes each (Table 2). In addition, there were a number of considerably more general GO terms (eg. extracellular region, regulation of biological process, organismal physiological process), which will not be considered further here. Of the five specific GO terms or groups of GO terms, two were characterized by uniformly increased gene expression (apoptosis and response to stress), one by uniformly decreased gene expression (collagen), and two by both increases and decreases in gene expression (protein kinase activity and ion transport). For all five the magnitude of expression changes of the constituent genes did not exceed \pm 2 -fold. Table 3 lists the individual genes that belonged to the three GO terms or groups with uniform directionality of expression changes as well as their respective fold changed expression values.

Figure 1 compares the number and magnitude of gene expression changes in the lung with that reported

Table 1 Diabetes altered the expression of a relatively small number of genes in the lung

\begin{tabular}{llll}
\hline $\begin{array}{l}\text { Fold change } \\
\text { threshold }\end{array}$ & $\begin{array}{l}\text { Total } \\
\text { number of } \\
\text { genes }\end{array}$ & $\begin{array}{l}\text { Genes with } \\
\text { increased } \\
\text { expression }\end{array}$ & $\begin{array}{l}\text { Genes with } \\
\text { decreased } \\
\text { expression }\end{array}$ \\
\hline \pm 1.5 & 46 & 19 & 27 \\
\pm 2 & 5 & 2 & 3 \\
\pm 3 & 1 & 1 & 0 \\
\hline
\end{tabular}

Data are depicted for various fold-change thresholds, and are indicated separately for all genes with significantly changed expression, just those with increased expression, and just those with decreased expression. ( $n=5,7$ for control and diabetic, respectively).
Table 2 Five major specific gene ontology (GO) groupings with statistically significant over-representation among genes with at least 1.5 -fold changed expression in diabetic compared with normal lung

\begin{tabular}{|c|c|c|}
\hline Specific GO term & $\begin{array}{l}\text { Number of } \\
\text { genes }\end{array}$ & P Value \\
\hline \multicolumn{3}{|l|}{ Terms Related to collagen } \\
\hline Collagen & 3 & 0.0024 \\
\hline Fibrillar Collagen & 2 & 0.025 \\
\hline \multicolumn{3}{|l|}{ Terms Related to Ion Transport } \\
\hline Ion Transporter Activity & 8 & 0.014 \\
\hline Cation Transporter Activity & 7 & 0.016 \\
\hline \multicolumn{3}{|l|}{$\begin{array}{l}\text { Terms Related to Apoptosis and } \\
\text { Cell Death }\end{array}$} \\
\hline Programmed Cell Death & 5 & 0.025 \\
\hline Death & 5 & 0.026 \\
\hline Cell Death & 5 & 0.026 \\
\hline Apoptosis & 5 & 0.030 \\
\hline \multicolumn{3}{|l|}{ Terms Related to Response to Stress } \\
\hline Response to Stress & 5 & 0.033 \\
\hline \multicolumn{3}{|l|}{$\begin{array}{l}\text { Terms Related to Regulation of } \\
\text { Kinase Activity }\end{array}$} \\
\hline Regulation of Protein Kinase Activity & 4 & 0.036 \\
\hline Regulation of Kinase Activity & 4 & 0.038 \\
\hline $\begin{array}{l}\text { Positive Regulation of Protein } \\
\text { Kinase Activity }\end{array}$ & 3 & 0.048 \\
\hline
\end{tabular}

previously for the heart in a study from our laboratory that used the same model of type 1 diabetes and the same methodology as the present study [20]. The heart had many more genes with diabetes-induced altered expression than the lung (261 vs. 46 genes, respectively). Furthermore, the maximum magnitudes of the changes in expression were higher in the heart than the lung (range in fold changes of -13.0 to 14.6 vs. -2.6 to 3.8, respectively). Consequentially the disease load index (summation of the absolute magnitude of fold changes for all genes with altered expression) $[20,30]$ was considerably higher for the heart than the lung (583.2 vs. 81.5, respectively).

Results of RT-PCR studies that confirmed gene expression array data are depicted in Figure 2. The direction of the expression changes were identical for expression array and PCR data, and the gene expression changes measured by PCR were statistically significant (range $\mathrm{P}<0.05$ to $\mathrm{P}<0.001$ ). In addition gene array and PCR data were correlated with each other $(r=0.97$, $\mathrm{P}<0.001)$. 
Table 3 Specific genes assigned to the gene ontology groups for which the direction of the expression changes were uniform

\begin{tabular}{|c|c|c|c|}
\hline $\begin{array}{l}\text { Gene } \\
\text { symbol }\end{array}$ & Gene name & $\begin{array}{l}\text { Gene } \\
\text { ID }\end{array}$ & $\begin{array}{l}\text { Fold } \\
\text { change }\end{array}$ \\
\hline \multicolumn{4}{|c|}{ Apoptosis and Cell Death } \\
\hline Len2 & lipocalin 2 & 170496 & 1.94 \\
\hline Gadd45b & $\begin{array}{l}\text { growth arrest and DNA-damage- } \\
\text { inducible } 45 \text { beta }\end{array}$ & 299626 & 1.73 \\
\hline Klf10 & Kruppel-like factor 10 & 81813 & 1.63 \\
\hline Ebag9 & $\begin{array}{l}\text { estrogen receptor-binding } \\
\text { fragment-associated gene } 9\end{array}$ & 299864 & 1.59 \\
\hline Prkaa1 & $\begin{array}{l}\text { protein kinase, AMP-activated, } \\
\text { alpha } 1 \text { catalytic subunit }\end{array}$ & 65248 & 1.58 \\
\hline \multicolumn{4}{|c|}{ Response to Stress } \\
\hline Ctgf & connective tissue growth factor & 64032 & 1.77 \\
\hline Gadd45b & $\begin{array}{l}\text { growth arrest and DNA-damage- } \\
\text { inducible } 45 \text { beta }\end{array}$ & 299626 & 1.73 \\
\hline Cd14 & CD14 antigen & 60350 & 1.68 \\
\hline Prkaa1 & $\begin{array}{l}\text { protein kinase, AMP-activated, } \\
\text { alpha } 1 \text { catalytic subunit }\end{array}$ & 65248 & 1.58 \\
\hline Lbp & lipopolysaccharide binding protein & 29469 & 1.56 \\
\hline \multicolumn{4}{|l|}{ Collagen } \\
\hline Col15a1 & procollagen, type XV & 298069 & -1.88 \\
\hline Col1a1 & procollagen, type 1, alpha 1 & 29393 & -1.85 \\
\hline Col3a1 & procollagen, type III, alpha 1 & 84032 & -1.70 \\
\hline
\end{tabular}

\section{Discussion}

The present study used a genome-wide expression approach to characterize alterations in lung gene expression by streptozotocin-induced diabetes in rats. Several specific areas were noted with altered gene expression, three of which had uniform directional changes (apoptosis/cell death, response to stress and collagen) and two of which had heterogeneous directional changes (protein kinase activity and ion transport). Nonetheless, the number of genes with altered expression, and the magnitude of the changed expression, were modest compared with findings in most other (albeit not all) tissue types reported previously [13,15-21,31].

Several GO groups of genes with streptozotocininduced diabetes altered expression found in the present lung study have previously been identified in gene expression array studies of other organ systems. Diabetesinduced changed gene expression related to apoptosis and/or cell death has been found in spleen [15], skeletal muscle [19], and lens [16]. Gene expression changes related to response to stress have been found in skeletal muscle [19] and lens [16]. Collagen gene expression changes have been found in skeletal muscle [21,31], corpus cavernosum [17], and heart [20]. Thus lung and other tissue types share at least some of the effects of type 1 diabetes on gene expression.

A previous study found differences among tissue types (kidney, heart, skeletal muscle and retina) in the effects of diabetes on gene expression [19]. In the present study, two gene groups identified as having changed expression with diabetes in the lung were not identified as having

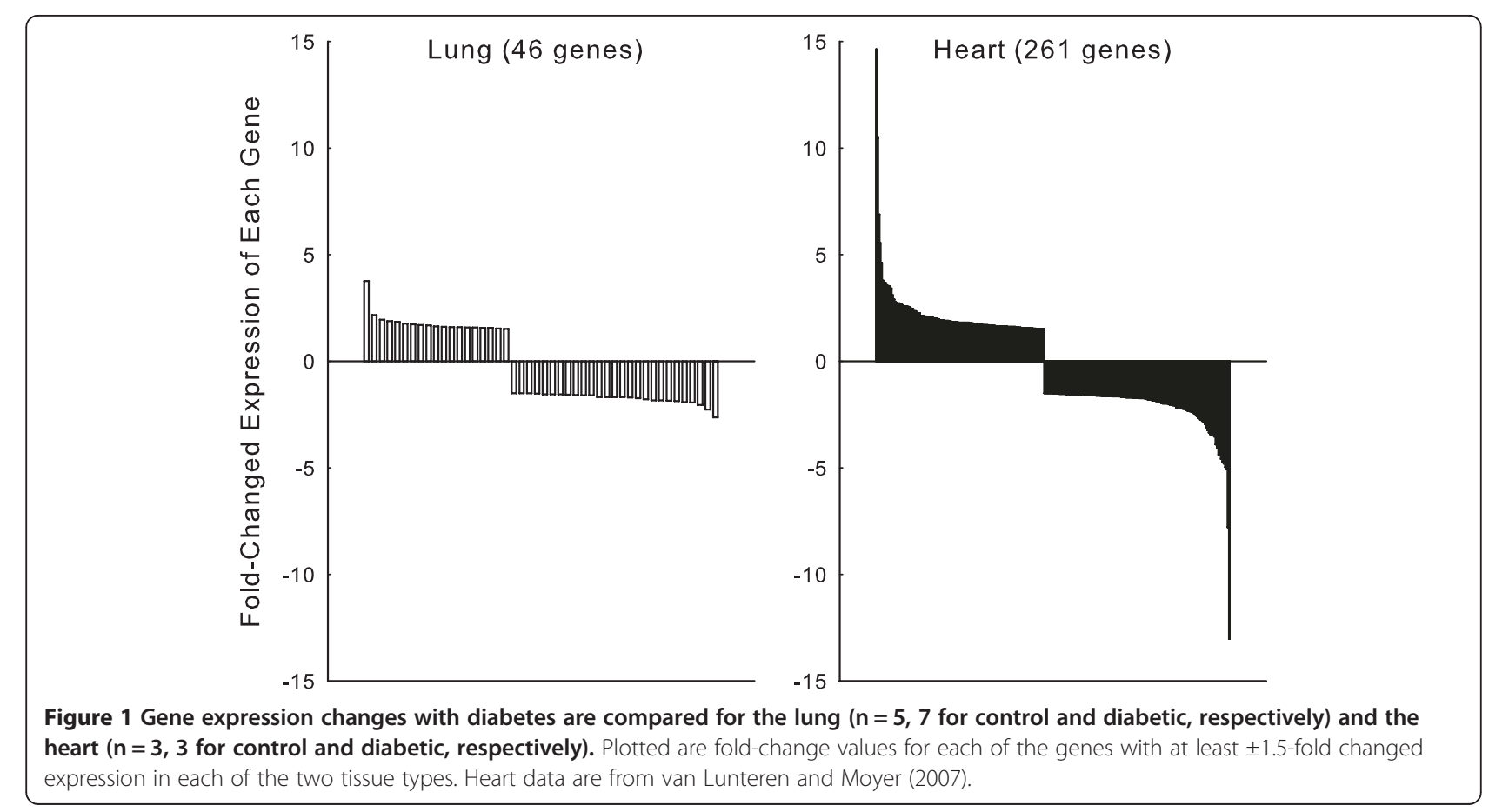




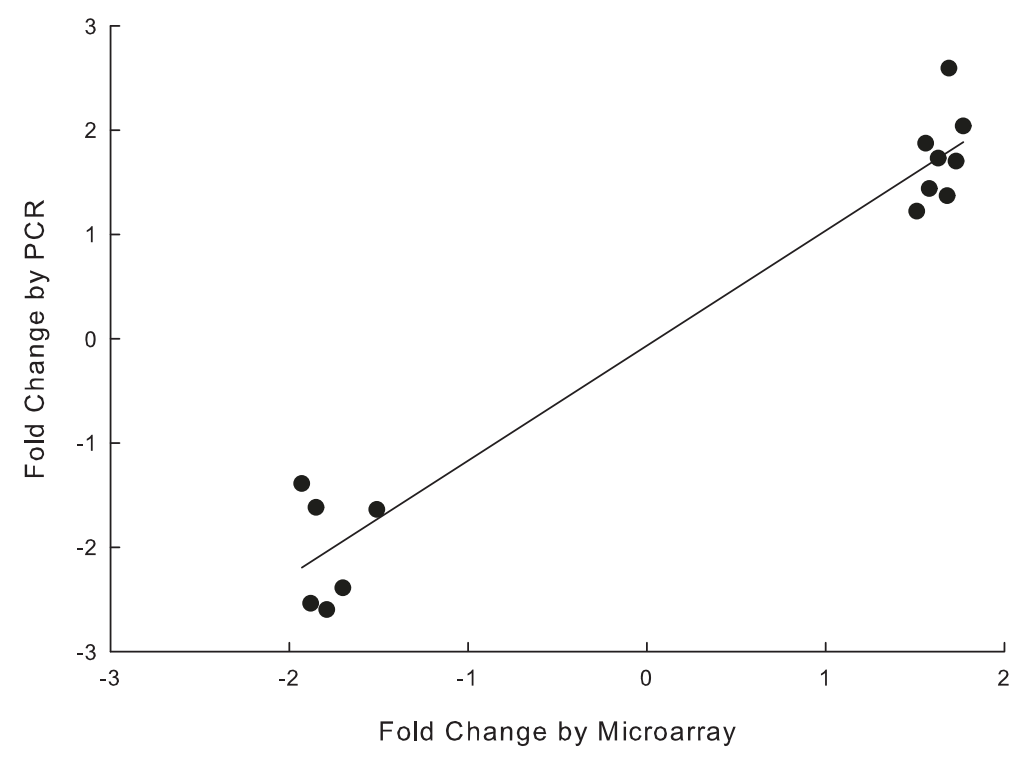

Figure $\mathbf{2}$ Changes in gene expression in diabetic lung measured by RT-PCR are compared with values obtained with gene expression microarrays. All genes had significantly altered expression by microarrays. ( $n=5,7$ for control and diabetic, respectively). Data are well correlated $(r=0.97, P<0.001)$.

changed expression in a number of gene expression array studies examining other tissues, namely protein kinase activity and ion transport [13,15-21,31]. Conversely, many GO groups of genes with changed expression in other tissues were not found to have changed expression in the lung. One notable area is that of energy production, including lipid and carbohydrate metabolism, which has been identified as having changed expression with type 1 diabetes in skeletal muscle $[19,21]$, heart [18-20], and kidney [19]. Another area is that of oxidative stress, for which gene expression changes have been described with type 1 diabetes in corpus cavernosum [17] and heart $[18,20]$. One limitation of such direct comparisons of tissue types is the methodological heterogeneity among studies with regards to the specific model of type 1 diabetes studied, the type of gene expression array, and the data analysis and statistical approaches. However, a previous study of the heart from our laboratory [20] used the same methodological strategies as the present study, and identified cardiac changes related to lipid metabolism, oxidoreductase activity and calcium ion binding which were not found in the lung in the present study. This suggests that lung has tissuespecific gene expression responses to type 1 diabetes in addition to the shared responses already mentioned.

Among the five GO terms or groups of GO terms identified as having changed gene expression in the lung with type 1 diabetes, apotosis/cell death is an attractive candidate process that may contribute importantly to the genesis of functional impairment of the lung. Interestingly, insulin inhibits apoptosis [32] and furthermore tight glycemic control accomplished with exogenous insulin or pancreatic transplantation attenuates and/or reverses type 1 diabetes-induced pulmonary function abnormalities [2,33]. Furthermore, osteopontin-deficient mice with streptozotocin-induced diabetes have milder cardiomyopathy and reduced apoptosis compared with wildtype mice with streptozotocin-induced diabetes [34], supporting the involvement of apotosis in diabetes-induced organ dysfunction (albeit that of cardiac muscle). However, genes belonging to the other four $\mathrm{GO}$ terms or groups of GO terms, or even single genes not assigned to specific GO terms, may very well also play important roles in the genesis of pulmonary dysfunction with diabetes.

\section{Conclusions}

In summary, this study demonstrates that diabetes mellitus induced by streptozotocin alters gene expression in the lung of Wistar rats. Directionally uniform changes were noted for genes involved in three areas, apoptosis/cell death, response to stress and collagen, whereas directionally heterogeneous changes were noted for genes involved in the regulation of protein kinase activity and ion transport. Equally notable was the absence of changes in some processes such as carbohydrate and lipid metabolism that are implicated in diabetes-induced dysfunction in other tissues.

\section{Additional file}

Additional file 1: Table S1. Complete list of genes with statistically significant changes of at least \pm 1.5 -fold in diabetic compared with normal lung. ( $n=5,7$ for control and diabetic, respectively). 


\section{Competing interests}

The authors declare that they have no competing interests.

\section{Authors' contributions}

EVL conceived of the study, participated in its design and coordination and drafted the manuscript. SS carried out the initial gene analysis. MM isolated RNA, finished gene analysis and helped with manuscript. All authors read and approved final manuscript.

\section{Acknowledgements}

We would like to thank Dr. Patrick Leahy from the Gene Expression Array Core Facility of the Comprehensive Cancer Center of Case Western Reserve University.

These studies were supported by funding from the Department of Veterans Affairs (Veterans Health Administration).

Received: 7 October 2013 Accepted: 8 January 2014

Published: 15 January 2014

\section{References}

1. Boulbou MS, Gourgoulianis KI, Klisiaris VK, Tsikrikas TS, Stathakis NE, Molyvdas PA: Diabetes mellitus and lung function. Med Princ Pract 2003, 12:87-91.

2. Dieterle CD, Schmauss S, Arbogast H, Domsch C, Huber RM, Landgraf R: Pulmonary function in patients with type 1 diabetes before and after simultaneous pancreas and kidney transplantation. Transplantation 2007, 83:566-569.

3. Kaparianos A, Argyropoulou E, Sampsonas F, Karkoulias K, Tsiamita M, Spiropoulos K: Pulmonary complications in diabetes mellitus. Chron Respir Dis 2008, 5:101-108.

4. Schnack C, Festa A, Schwarzmaier-D'Assié A, Haber P, Schernthaner G: Pulmonary dysfunction in type 1 diabetes in relation to metabolic long-term control and to incipient diabetic nephropathy. Nephron 1996, 74:395-400.

5. Villa MP, Montesano M, Barreto M, Pagani J, Stegagno M, Multari G, Ronchetti R: Diffusing capacity for carbon monoxide in children with type 1 diabetes. Diabetologia 2004, 47:1931-1935.

6. Wanke T, Formanek D, Auinger M, Zwick H, Irsigler K: Pulmonary gas exchange and oxygen uptake during exercise in patients with type 1 diabetes mellitus. Diabet Med 1992, 9:252-257.

7. Scano G, Filippelli M, Romagnoli I, Mancini M, Misuri G, Duranti R, Rosi E: Hypoxic and hypercapnic breathlessness in patients with type I diabetes mellitus. Chest 2000, 117:960-967.

8. Wanke T, Lahrmann H, Auinger M, Merkle M, Formanek D, Ogris E, Irsigler K, Zwick H: Endogenous opiod system during inspiratory loading in patients with type 1 diabetes. Am Rev Respir Dis 1993, 148:1335-1340.

9. Hsia CC, Raskin P: The diabetic lung: relevance of alveolar microangiopathy for the use of inhaled insulin. Am J Med 2006, 118:205-211.

10. Garnett KE, Chapman P, Chambers JA, Waddell ID, Boam DS: Differential gene expression between Zucker Fatty rats and Zucker Diabetic Fatty rats: a potential role for the immediate-early gene Egr-1 in regulation of beta cell proliferation. J Mol Endocrinol 2005, 35:13-25.

11. Baelde HJ, Eikmans M, Doran PP, Lappin DW, de Heer E, Bruijn JA: Gene expression profiling in glomeruli from human kidneys with diabetic nephropathy. Am J Kidney Dis 2004, 43:636-650.

12. Fan Q, Shike T, Shigihara T, Tanimoto M, Gohda T, Makita Y, Wang LN, Horikoshi S, Tomino Y: Gene expression profile in diabetic KK/Ta mice. Kidney Int 2003, 64:1978-1985.

13. Wilson KH, Eckenrode SE, Li QZ, Ruan QG, Yang P, Shi JD, DavoodiSemiromi A, McIndoe RA, Croker BP, She JX: Microarray analysis of gene expression in the kidneys of new- and post-onset diabetic NOD mice. Diabetes 2003, 52:2151-2159.

14. Suh YH, Kim Y, Bang JH, Choi KS, Lee JW, Kim WH, Oh TJ, An S, Jung MH: Analysis of gene expression profiles in insulin-sensitive tissues from pre-diabetic and diabetic Zucker diabetic fatty rats. J Mol Endocrinol 2005, 34:299-315.

15. Eckenrode SE, Ruan Q, Yang P, Zheng W, Mclndoe RA, She JX: Gene expression profiles define a key checkpoint for type 1 diabetes in NOD mice. Diabetes 2004, 53:366-375.
16. Kubo E, Singh DP, Akagi Y: Gene expression profiling of diabetic and galactosaemic cataractous rat lens by microarray analysis. Diabetologia 2005, 48:790-798,

17. Sullivan CJ, Teal TH, Luttrell IP, Tran KB, Peters MA, Wessells H: Microarray analysis reveals novel gene expression changes associated with erectile dysfunction in diabetic rats. Physiol Genomics 2005, 23:192-205.

18. Gerber LK, Aronow BJ, Matlib MA: Activation of a novel long-chain free fatty acid generation and export system in mitochondria of diabetic rat hearts. Am J Physiol 2006, 291:C1198-C1207.

19. Knoll KE, Pietrusz JL, Liang M: Tissue-specific transcriptome responses in rats with early streptozotocin-induced diabetes. Physiol Genomics 2005, 21:222-229.

20. van Lunteren E, Moyer M: Oxidoreductase, morphogenesis, extracellular matrix and calcium ion binding gene expression in streptozotocin-induced diabetic rat heart. Am J Physiol Endocrinol Metab 2007, 293:E759-E768.

21. Lecker SH, Jagoe RT, Gilbert A, Gomes M, Baracos V, Bailey J, Price SR, Mitch WE, Goldberg AL: Multiple types of skeletal muscle atrophy involve a common program of changes in gene expression. FASEB J 2004, 18:39-51.

22. Sreekumar R, Halvatsiotis P, Schimke JC, Nair KS: Gene expression profile in skeletal muscle of type 2 diabetes and the effect of insulin treatment. Diabetes 2002, 51:1913-1920.

23. Voss MD, Beha A, Tennagels N, Tschank G, Herling AW, Quint M, Gerl M, Metz-Weidmann C, Haun G, Korn M: Gene expression profiling in skeletal muscle of Zucker diabetic fatty rats: implications for a role of stearoylCoA desaturase 1 in insulin resistance. Diabetologia 2005, 48:2622-2630.

24. Hida W, Shindob C, Satoh J, Sagara M, Kikuchi Y, Toyota T, Shirato K: N-acetyl inhibits loss of diaphragm function in streptozotocin-treated rats. Am J Crit Care Med 1996, 153:1875-1979.

25. van Lunteren E, Moyer M, Leahy P: Gene expression profiling of diaphragm muscle in alpha2-laminin (merosin)-deficient dy/dy dystrophic mice. Physiol Genomics 2006, 25:85-95.

26. van Lunteren E, Spiegler S, Moyer M: Contrast between cardiac left ventricle and diaphragm muscle in expression of genes involved in carbohydrate and lipid metabolism. Respir Physiol Neurobiol 2008, 161:41-53.

27. Ishwaran H, Rao JS: Detecting differentially expressed genes in microarrays using Bayesian model selection. J Am Stat Assoc 2003, 98:438-455.

28. Dennis G, Sherman BT, Hosack DA, Yang J, Gao W, Lane HC, Lempicki RA: DAVID: data base for annotation, visualization, and integrated discovery. Genome Biol 2003, 4:R60.

29. Hosack DA, Dennis G, Sherman BT, Lane HC, Lempicki RA: Identifying biological themes within lists of genes with EASE. Genome Biol 2003 4:R70.

30. Porter JD, Merriam AP, Leahy P, Gong B, Feuerman J, Cheng G, Khanna S: Temporal gene expression profiling of dystrophin-deficient ( $\mathrm{mdx}$ ) mouse diaphragm identifies conserved and muscle-group specific mechanisms in the pathogenesis of muscular dystrophy. Hum Mol Genet 2004, 13:257-269.

31. Lehti TM, Silvennoinen M, Kiveli R, Kainulainen H, Komulainen J: Effects of streptozotocin-induced diabetes and physical training on gene expression of extracellular matrix proteins in mouse skeletal muscle. Am J Physiol Endocrinol Metab 2006, 290:E900-E907.

32. lida KT, Suzuki H, Sone H, Shimano H, Toyoshima H, Yatoh S, Asano T, Okuda Y, Yamada N: Insulin inhibits apoptosis of macrophage cell line, THP-1 cells, via phosphatidylinositol-3-kinase-dependent pathway. Arterioscler Thromb Vasc Biol 2002, 22:380-386.

33. Ramirez LC, Dal Nogare A, Hsia C, Arauz C, Butt I, Strowig SM, Schnurr-Breen L, Raskin P: Relationship between diabetes control and pulmonary function in insulin-dependent diabetes mellitus. Am J Med 1991, 91:371-376.

34. Subramanian V, Krishnamurthy P, Singh K, Singh M: Lack of osteopontin improves cardiac function in streptozotocin-induced diabetic mice. Am J Physiol Heart Circ Physiol 2007, 292:H673-H683.

doi:10.1186/1472-6823-14-5

Cite this article as: van Lunteren et al:: Alterations in lung gene expression in streptozotocin-induced diabetic rats. BMC Endocrine Disorders 2014 14:5. 